\title{
"Le cabanon du fou": \\ Uses of the Shed As a Confinement Device \\ for the Insane in French Rural Households \\ in the I9th Century
}

Anatole Le Bras

Last April 25, police officers passing in Mons-Boubers learned that, for approximately two years, Delphine Roussel, aged 33, had not left the house of her father, and that the latter, when asked about her, always answered that she was sick and staying in bed.

The law enforcement officials, whose suspicions were aroused, asked to see Delphine Roussel. They saw that the poor creature was confined in a robust shed, built in the corner of a room with closed shutters. In this very small recess, closed with a wooden door and an enormous lock, Delphine Roussel, pale and thin, was crouching on rotten straw, exhaling a disgusting smell.

She had no clothes but an old petticoat; excrement had accumulated in a corner.... An opening in one of the walls of her cell barely let enough air in, and was used to convey her some food.

Delphine Roussel explained that she had been confined for two years in this recess, where she never saw daylight and spent the winter without fire and with no other clothes than the petticoat she was covered with.' 
This sensational story, reported by the newspaper Le Petit Journal in the summer of I879, may sound exceptional, but actually resembles dozens of other similar cases of scandals of illegal sequestrations of mentally ill persons by their families. Working on these affairs, I was struck by the omnipresence of cabanons, or "sheds" (most of the time made of wood boards), mirroring contemporary practices of confinement in rural Indonesia, known as pasung ${ }^{2}$, which sometimes involved the building of a wood cabin for keeping the mentally ill.

Mental institutions never have had a total monopoly on the confinement of the insane. And yet, household sequestrations of mentally ill persons are a phenomenon that attracted little attention from historians. Charlotte Brontë's (I816-I855) "madwoman in the attic" 3 is well known, but it is difficult to know whether this literary figure corresponded to real social practices or not. A couple of cases of sequestrations are mentioned in the archives of the English Commissioners in Lunacy studied by Akihito Suzuki (2006: 166). David Wright, in his study of familial care of "idiot" 4 children in Victorian England, showed how "houses themselves became informal 'asylums', outside which the child was not supposed to go unattended" (1998: 188). However, these examples are piecemeal and neither sufficient to provide a detailed study of sequestration practices, nor to expose their motives. Therefore, a more systematic study requires finding new material. "Getting out of the asylum" (Wright 1997) and using judiciary archives will enable us to put families and communities, rather than doctors, at the center of the study. ${ }^{5}$

The study of the material culture of psychiatry offered stimulating insights about asylum life and social relations between doctors and patients (Majerus 20II), but less is known about objects used by families to take care of or manage their mentally ill kin. This paper uses a singular approach, focusing on a material item situated on the edges of psychiatry, and which became an object of psychiatric discourse only to be denounced. The shed was not an emblematic object of psychiatry, as the straitjacket could be. Quite the contrary, it served as an anti-model for French alienists. Studying the shed thus amounts to writing a decentered history of I9th-century psychiatry.

This article rests on a corpus of 47 cases of illegal sequestration, collected from the Gazette des tribunaux, a jurisprudence and legislation newspaper, Le Petit Journal, a newspaper with a nationwide audience and a print run of over a million copies in the I890s, and prominent psychiatry journals such as the Annales médico-psychologiques. ${ }^{6}$ While the analysis is mainly based on trial reports found in the newspapers, ${ }^{7}$ it also relies on several case files from the criminal court archives of three departments. ${ }^{8}$ 
According to article 475 of the Penal Code, ${ }^{9}$ the sequestration of a "lunatic" was not criminally reprehensible in itself and could be punished only if it had been accompanied by abuse or neglect. Hence the bias of our study: the practices of sequestration that can be studied through the prism of judiciary archives are only the most extreme. However, this article will try to show that these cases are nonetheless revelatory of norms of behavior and attitudes towards the mentally ill considered acceptable - or not - by the community and by the judicial authority. The number of acquittals was not negligible, especially if the accused managed to convince the jury that they had been compelled to confine the mentally ill person because of his or her violence, thus showing a certain degree of acceptance of the practice of sequestration. All of this suggests that even if the cases studied are just the tip of the iceberg, they tell us a lot about what is below.

In at least 16 of these 47 cases, the sequestration occurred in sheds. These could be placed inside the house, in annex buildings, or outside. The judiciary procedure entailed a wealth of details about the material conditions of confinement. During the trial of Granier (I866), a facsimile of the shed where the young Adeline had been confined for ten years was even exhibited to the jury. ${ }^{\text {Io }}$ The report of the trial explained that a doll was placed in the model house to help the jury understand the painful position Adeline was forced to adopt during her sequestration. The materiality of sheds was at the center of the legal authorities' attention and psychiatric discourse. For the historian, it is also highly revealing about family strategies for coping with the mental illness of their kin, and about the place of the lunatic in his or her family and community.

\section{The Shed:}

\section{An Object of Scandal and an Antimodel for 19th-Century Psychiatry}

The second half of the I9th century was, in France as in most European countries, the golden age of the asylum. Nonetheless, in three different and apparently unrelated settings, sheds came to the attention of alienists because they were still used to confine the mentally ill. In all these cases, they were condemned by psychiatric professionals as a symbol of the archaic nature of practices still prevailing outside modern asylums. 


\section{Hospital, Colonial, and Household Settings: A Multifaceted Device of Confinement}

In Ancien Régime and early-I9th-century hospitals and nursing homes, special "lodges" were used to confine raging lunatics (Petit 1980). They were made obsolete by the law of $1838^{\text {II }}$ that made asylums the only legitimate places of confinement for the insane. However, it turned out that hospital sheds were still in use in hospitals all over the country as late as in the i88os. They were used to accommodate lunatics whenever one of them was admitted - which happened frequently because article 24 of the law of 1838 provided for the possibility to temporarily send lunatics to hospitals or nursing homes before they were sent to the asylum. Their stay was supposed to be limited to I5 days, but this rule was not enforced, and lunatics could stay for several months in many hospitals.

In the late I880s, the alienist Désiré-Magloire Bourneville went on a tour of French hospitals to inquire about lunatics' living conditions and published several articles exposing their situation (Bourneville I889). He noted that most hospitals did not have proper isolation rooms for the insane. Most of them were placed in sheds. These were generally located outside the main buildings and could be near the pigsty (Lunéville), the stable (Arbois), or in the farmyard of the hospital (Bar-sur-Aube). They were devoid of any furniture, lacked heating, and the windows had no panes. Given their peripheral location, the lunatics placed in these sheds were not watched over, which led to many suicides. As Gabriel Monod, director of the Public Assistance, concluded: "It seems that old abuses, the most regrettable of ancient misguided ways, proscribed from asylums, continue to flourish in hospitals" (Monod I889: 3II).

The same could be said of new imperial spaces. In the early 2oth century, while psychiatrists' attention turned more and more to the colonies, it appeared that there, too, sheds were largely in use. French psychiatrists tried to document this reality of pre-colonial treatment of the insane, thus constructing a representation of indigenous means of treatment and care as archaic and barbaric. The following drawing (fig. I) of a shed used to confine the mentally ill in Siam and Laos was presented at the Congress of Tunis in I9I2.

The doctors Solomon Lwoff and Paul Sérieux (I9II) also published photographs of tools of containment used in the sheds of Fez hospital, such as iron necklaces and shackles. Their stated goal was to convince the authorities to set up a modern system of psychiatric care in the colonies in order to put an end to such practices.

The same motive pushed the alienists to express their concerns about the use of sheds by French families - especially in the countryside. Starting in the I840s, a 


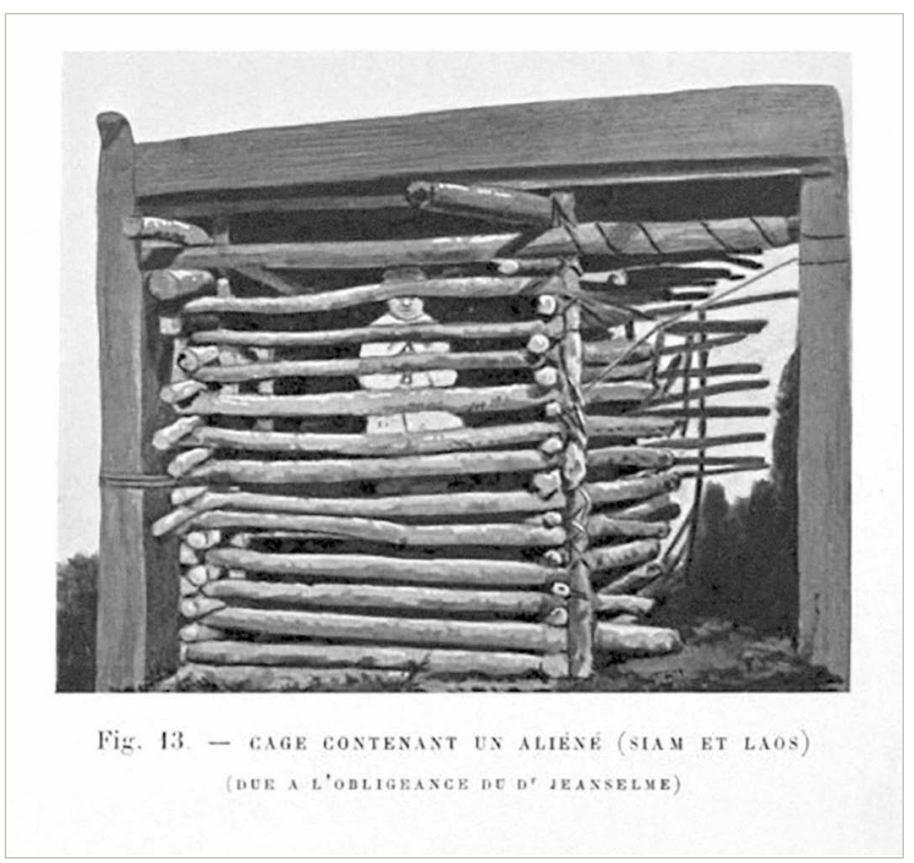

number of articles in psychiatric journals commented on cases of the sequestration of lunatics by their own families. These publications generally coincided with two types of events: a new sequestration scandal that spurred a series of reactions or debates, or parliamentary debates about the revision of the I838 law. After he witnessed a case of sequestration in Toulouse, the alienist Victor Parant ${ }^{12}$ (I884) published the first systematic study on the topic of household sequestrations. Gabriel Izard (1903), a colonial army doctor, published his study on the same topic not long after the scandal of the "séquestrée de Poitiers," in 190I. ${ }^{13}$

These concerns about the situation of lunatics kept at home must be replaced in the context of a longstanding effort by alienists to encourage and facilitate placements in asylums - at the expense of families if necessary. Now that they had succeeded in setting up a national system of care and to have their professional competency recognized, alienists were willing to expand their control over new domains, such as colonies, hospitals, and households. 


\section{An "Archaism" That Questioned the Flaws of the French Psychiatric Legislation}

For French alienists, the shed was not just an inappropriate way to confine the mentally ill. It also revealed the mentality of the rural population. The doctors analyzed sequestrations through the lens of an urban elite, who was socially very distant from rural classes.

According to them, the main explanation of sequestrations was peasants' greed. Their so-called selfishness, egoism, and avarice were endlessly commented on. The insane were kept at home because rural people were willing to avoid contributing to the cost of asylum care. But bad treatment inflicted upon the mentally ill also reflected the peasants' archaic mindset. Commenting on a case of sequestration, the medical superintendent of the Quimper public asylum (Brittany) admitted that means of appropriate treatment were not easily accessible in the countryside. But he also added that "prejudices are still excessive toward the mentally ill" (Baume 1874: 418). The practice of sequestration was part of a set of old beliefs. After having received a young "idiot," who had been locked in a shed for a month in his village of the rural Pyreneans, the superintendent of the Pau Public Asylum interpreted his sequestration as a result of the fear that mental alienation inspired to peasants, who tended to confuse insanity with demonic possession (Girma/Vernet 1894). The negligence and indifference of neighbors and local authorities was also often criticized. All strata of the rural society were deemed collectively responsible for inhumane treatment of the mentally ill. The sequestrations were also used strategically in the public discourse of the psychiatric profession. It enabled them to reverse the accusation of wrongful confinement launched by hostile "anti-alienist" campaigns ${ }^{14}$ : "It is among private individuals, and in the families, not in the asylums, that arbitrary sequestrations, negligence, abuses are to be feared," exclaimed Achille Foville ${ }^{15}$ (1870: 407).

These cases nonetheless led the psychiatrists to question the existing legislation and system of psychiatric care. First, they deplored the fact that the I838 law remained totally silent regarding the mentally ill outside of asylums, contrary to the English or Scottish legislation, which were often cited as models. ${ }^{16}$ They also agreed that the committal of "idiots," epileptics, and more generally all lunatics deemed inoffensive should be facilitated.

Second, psychiatrists called into question the common law and the penal code of I8Io. Indeed, all these scandals revealed that sequestrating a mentally ill person was not illegal in itself. Article $475, \$ 7$ of the French penal code punishing those who let an insane person, "a raving lunatic," or "a ferocious animal" who was supposed to 
be in their custody roam freely, created an exception to article 34I, which punished unlawful sequestration. "In other words," Victor Parant (I884: 8) commented, "the law allows the families to sequestrate in their household those of their members who are affected by mental alienation. This right is not submitted to any restriction." As a consequence, many French psychiatrists advocated the creation of a special institution, on the model of the British Commissioners in Lunacy, dedicated to controlling the treatment of the mentally ill kept in their households.

The attitude of the legislator and of public authorities was nonetheless ambiguous. Concerns were raised as to whether such a system of surveillance would lead to an infringement over the intimacy of families. The legislator was not really willing to attack the "rights of the families," and the various projects of reform of the I 838 law that were debated at the Chamber of Deputies throughout the igth century were very cautious on the topic of surveillance of lunatics outside the asylum - apart from the reform supported by the socialist member of parliament Édouard Vaillant (I840I9I5) in I894, which was largely dismissed by the Chamber (Hubert I902: I54-I57). ${ }^{17}$

The shed, as a tool of confinement, can thus be understood as an expression of

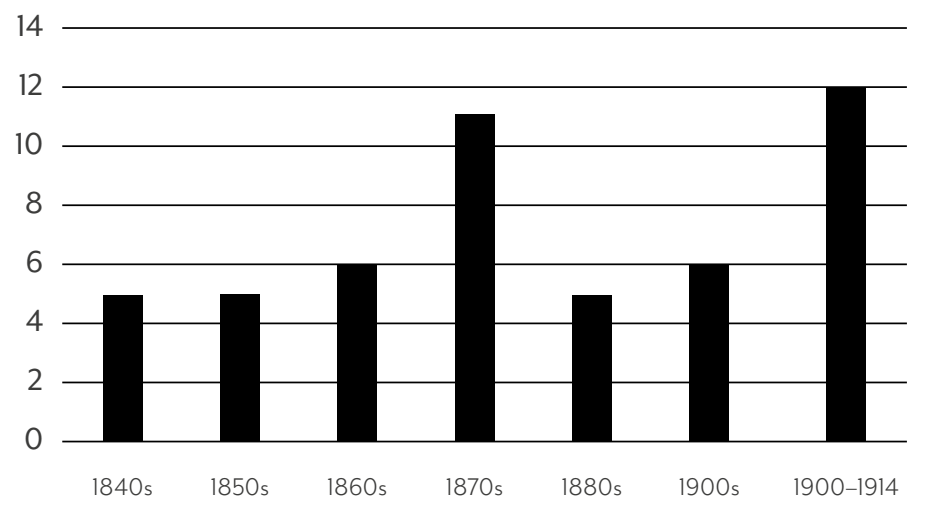


the sovereignty of the family over its members. ${ }^{18}$ Despite denunciatory discourses, the number of cases of illegal sequestrations did not seem to decrease in the second half of the century.

These figures are obviously not exhaustive, and they tell us more about media coverage than about the real number of sequestrations (the high figures of the last decade can be attributed to the repercussions of the "séquestrée de Poitiers" in I90I); yet the trend was clearly not toward a decline or disappearance of scandals.

The persistence of sequestrations and the periodic resurgence of the shed indicate that understanding it only as an archaism is not sufficient. It is necessary to analyze it as an object that shaped the relations between the lunatics and their families.

\section{Confining the Insane at Home: A Study of Material Practices of Confinement in 19th-Century French Families}

The most well-known of sequestration cases (that of Poitiers in I90I) was used by novelist André Gide (1930) to denounce the oppressive atmosphere of bourgeois families. However, sequestrations happened most of the time in rural areas and farmers' families.

Gender clearly played a role in the decision to confine. The number of sequestrated women in our corpus of cases (32) is almost two times the number of men (I7). ${ }^{19}$ The most common forms of mental alienation are, not surprisingly, idiocy, imbecility, and others forms of mental deficiency. However, a detailed study of the reports shows that this state of idiocy could be a consequence rather than a cause of the sequestration. Many of the sequestrated were not affected by congenital diseases, but by various types of mania, dementia, hysteria, etcetera, which appeared in their adulthood. Some of the victims were old people afflicted by senile dementia, but usually the confinement began while the mentally ill were still under 30 years old..$^{20}$

A brief overview of the identity of those deemed responsible for the sequestration shows that confining an insane person was mostly a prerogative of the closest kin. The parents were involved in more than half the cases. Confining the insane was a way for the close relatives to keep them under their control. It was also a manifestation of parental and male authority ( 42 men involved versus 28 women). The sequestration was usually a long-term strategy: in more than half the cases considered, the sequestration lasted for more than a year. 


\section{The Shed As a Last Resort for Managing the Insane}

One of the main motives for sequestration was the fear of public shame. "He was bringing shame on us!" exclaimed the father of Albin Le Gouallec. ${ }^{21}$ When a member of the family started acting like an insane person in public, the honor and reputation of the lineage were at stake. Revealing the mental illness of the member of the household entailed the risk of tarnishing the reputation of the whole lineage and threatened matrimonial projects. A lunatic was also seen by other family members as a risk for property - be it that of the family or that of neighbors. While free, Albin Le Gouallec was accused by his father (and by several village dwellers) to have broken a pane at the village chapel and to have damaged his fathers' fields. ${ }^{22}$ Later, after Albin had been locked in the stable, the mayor asked his father to unchain his son. He replied that he would consent to do it only if the mayor accepted to take full responsibility for the acts that his son might commit, and to pay for all damages he may cause to the property of village dwellers. Nobody being ready to take that risk, it seems that the mayor agreed tacitly to the prolongation of Albin's sequestration.

The recourse to household sequestration must also be understood as the failure or rejection of other options that appeared too costly or too difficult for the family. During his trial, the father of Delphine Roussel explained that he could not find anybody willing to be hired as a guardian for his daughter. The mayor of Mons-Boubert had advised him to do his best to keep her by himself, because the Roussel family was not indigent and therefore would not obtain a free committal to the local asylum. In this case as in many others, the main obstacle to the committal of the lunatic appears to have been the cost of such a measure for the family and for the municipality. ${ }^{23}$

As Akihito Suzuki (2006: II7) observed, "the existence of a lunatic in a family destabilized the boundary between the public and private spheres and invited forceful intervention from the outside world." The shed was a response to this threat. It was a way to reaffirm the boundary between the private and the public, to maintain the family's autonomy vis-à-vis outside authorities. However, the barriers inside which families tried to keep the insane were under constant threat, because of the reactions of the insane person himself but also because of the intrusions of neighbors and local authorities. In I873, Delphine Roussel's father built a shed inside the house, with a louvered door. In the beginning, his daughter only slept there and was free to move during the day, except when her parents were working on their distant fields. She was also permitted to go to mass every Sunday. But from I877 onwards, her confinement became permanent. One day in July I878, she managed 
to get out and broke the clock and some vases. The risk of material damage caused by the lunatic was often decisive in the decision to sequestrate. Delphine's father replaced the louvered door of the shed with a more solid door without openwork.

It is thus necessary to place the shed in a range of more or less tight control and surveillance means. Married in I827, Ismérie Danchelle, from the Ardennes department ${ }^{24}$, apparently suffered from puerperal mania following her second child delivery. Unable to take care of her because of his professional occupation, her husband entrusted her to her parents, in exchange for a monthly pension. The parents agreed to take care of her, but after having called a doctor once, they refused to pay for any more medical care. Ismérie's health deteriorated quickly, and she began acting in an unconventional way: she ran after men in the streets, went outside naked, etcetera. Her parents first locked her up in a room. After she broke the window panes several times, they added wooden bars at the windows. But she somehow managed to break them and escape. Finally, they built the shed in which they would confine Ismérie for eight years.

Building a shed was generally the result of similar series of improvisations and adaptations to an unpredictable behavior and/or a decreasing degree of tolerance. The study of the shed's material features confirms that its primary function was to keep the insane person from doing harm at a minimal cost. When it was possible, the shed was made of a preexisting structure. In that respect, it is worth noting a specificity of the region of Brittany: the use of the closed bed [lit clos]. Generally I.6 to I.7 meters long, out of fashion in the east but still used in the more traditional west of Brittany, known as Basse-Bretagne, this piece of furniture was used at the same time as a bed, a cupboard and bench. It was opened only on one side and could usually be hermetically closed by a door or a shutter. Several sequestration cases, but also some patients' case histories in the archives of the Quimper public asylum ${ }^{25}$ show that closed beds were frequently used as a device of confinement for the insane, as in the Cadiou case.

Two closed beds were juxtaposed in the main room of the Cadiou house, in order to create a confined space from which it was impossible to escape on both sides (fig. 2). A heavy wooden door was added on the third side, and the window on the wall was obstructed. The young Anne-Marie stayed there for more than four years. Her case illustrates the adaptation of existing house furniture to new purposes, a process through which an ordinary piece of furniture could acquire a new role and meaning as object of management of the mentally ill. Here the closed bed seems to have been a particularly practical tool of confinement because of its robustness 


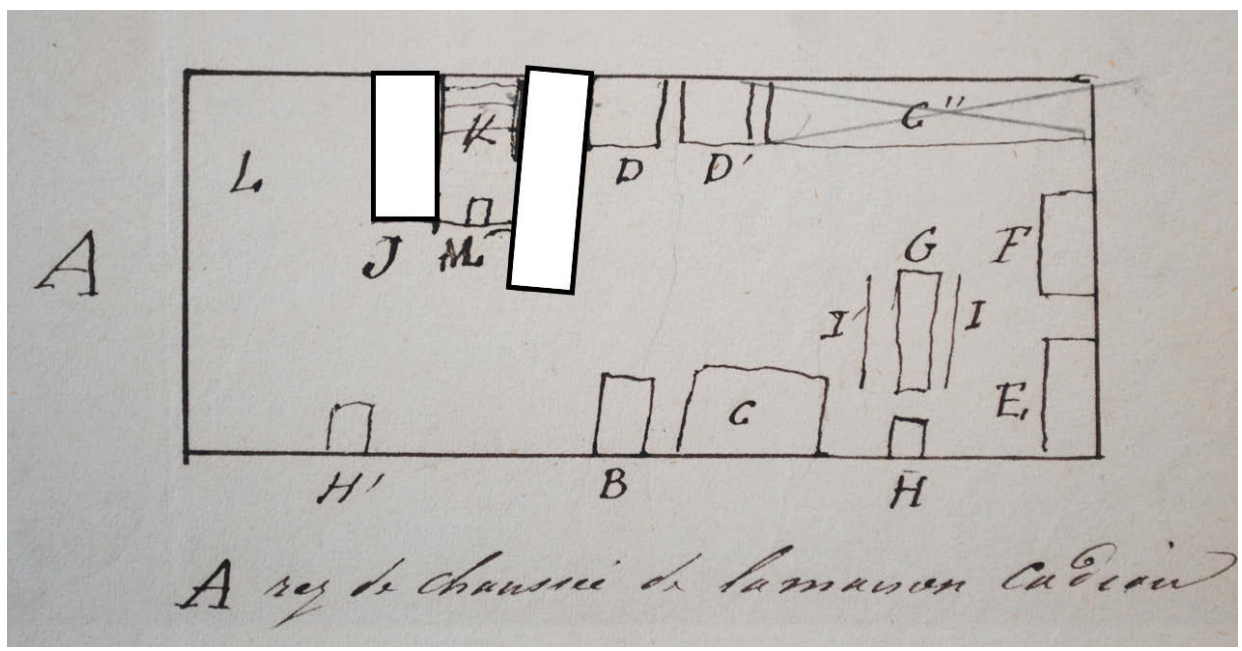

and because it could easily be locked from the outside. The same applies to specific units of the farmhouse that could become a shed of confinement. This was the case in Jaunay's case ${ }^{26}$ in 1903. Jaunay was a 23-year-old, who became very agitated. Because the administrative procedure to commit her to the public asylum was very time-consuming, her parents lost their patience and decided to lock her up in the rabbit hutch - which was not even cleaned before accommodating her.

In other instances, however, the shed was built for the purpose of confinement, after other material forms of management had failed. The police officers were impressed by the solidity of the shed built by Delphine Roussel's father, made of brick and wood, so that his daughter could never escape again. The family members were sometimes helped by artisans of the village in this task. In the case of Le Gouallec, the father was assisted by the blacksmith of the village and by another farmer of the surroundings. ${ }^{27}$ This participation of other members of the community in the setting up of the device of confinement shows that the sequestration could be socially accepted. In the case of Roussel, by contrast, the mason and the carpenter that helped Delphine's father were not informed of the purpose of the strange hut they were asked to build in the corner of a room. 


\section{Mistreatment and Abuse}

The main objective of the shed was not only to confine the insane person and to prevent him or her from wandering in public, but also to drastically restrict his or her freedom of movement. It was often combined with other devices of containment: for example, Albin Le Gouallec was chained to the main beam of the stable for approximately three years. The chain weighed two kilograms, and at first it was not even long enough to allow his foot to touch the ground, so that he had to lie on the ground with one foot up. During the investigation, the key was nowhere to be found - a sign that Albin's containment was meant to be permanent and probably for the rest of his life. Besides being confined in a pig hut, Madeleine Pigniot was tied up with ropes. ${ }^{28}$ This desire to restrict freedom of movement can also be seen in the extremely small size of confinement spaces. In a case commented on by Victor Parant (I884:3-7), two sheds were built in a room for a young raving lunatic and his father. Both of them could nonetheless access a small cage situated in the yard of the house, where they had a little more freedom of movement. In many instances, the sequestrated were totally deprived of any light and air. During the trial of Jahan, the doctor Vaugiraud, called as a witness, underlined "that the shed contained just nine cubic meters of air, and what air? A stale air, coming from the stable where the manure was piled up." ${ }^{29}$

In the Cassany case,,$^{30}$ an "idiot" woman was confined in a piece of furniture just I.2 meters long and 78 centimeters wide. Lucien Bodeau could not stand in his shed, which was just I.4 meters high. ${ }^{\text {I }}$ Terrible conditions of hygiene ensued. Delphine Roussel was never allowed to go out, even for satisfying basic material needs: a layer of ten centimeters of excrement covered the soil of her shed when the police found her.

These extreme material conditions had spectacular effects on the bodies of the sequestered. The absence of freedom of movement could lead to a progressive loss of mobility functions for the persons confined, who also tended to keep their knees close to their shoulders, as a derisory protection against the cold. This situation was documented by a photograph published in I894 (fig. 3).

The doctors who presented Laporte's case at the La Rochelle congress of mental medicine in I893 explained that he had been found completely naked, unable to speak or walk, in a wooden shed of just one square meter, in his small village of Saligos, in the Pyrenees. The picture was taken not long after his arrival at the local public asylum. 
Most of the sequestered were found in an even worse state, emaciated, with long hair, beard, and nails, scars on the body, etcetera. The alienists who commented on sequestration scandals did not miss an opportunity to underscore the negative consequences of family confinement for the physical and mental health of the mad. They contrasted the mistreatment inflicted by the family with the modern standards of care and material comfort prevailing in asylums. Bad treatment was indeed frequent - as mentioned earlier, the accused were not so much tried for the sequestration as for the mistreatment and abuse that accompanied it.

Could these extremely harsh living conditions be a covert way to accelerate the coming of death? The answer was sometimes yes. In certain scandals, the will of the family to come into possession of the inheritance of the mentally ill person was a suspected motive for the sequestration. In the case of Le Gouallec, the father was even said to have promised the quick death of his son to his new son-in-law, who hoped to inherit the family farm. But most of the time, the way the mentally ill person was fed contradicts the idea that sequestrating was a roundabout way of killing. The persons confined were usually deprived of freedom, air, light, heat, but rarely of food. Sheds usually had a single opening: a small hatch through which their meals were delivered.

The abuse that went along with sequestrations seemed to rather result from a slow process of progressive degradation, growing indifference, and neglect, which is exactly the process that fascinated André Gide in the case of "la séquestrée de Poitiers": without any malevolent intention at first, the Monnier family was slowly driven to a barbaric behavior. ${ }^{32}$ However, bad treatment resulted from extreme situations of material deprivation. Ismérie Danchelle's mother told the jury how she had always tried to alleviate the plight of her daughter. But when the young woman ripped up all the clothes she was given, she was finally left naked. ${ }^{33}$ Albin Le Gouallec was fed with a broken piece of cauldron because his parents did not want him to break their plates. After Blancher Monnier smashed her chamber pots, she was deprived of them and had to relieve herself in her own bed. Most of the sequestered, however, did not sleep in a bed: all pieces of furniture were removed from their shed or room. They slept at best on a pallet, or on piles of straw. Bad treatment could also result from an incapacity to adequately cope with the manifestations of 
mental illness: when the sequestered were noisy or violent, some family members could imagine no other way to silence them than to beat them.

A series of recurrent material elements raises the question of the perceived animality of the mentally ill: the forced nudity, the impossibility of standing up, the similarity of sheds with cages, the fact that they were sometimes kept in spaces usually reserved for animals. Albin Le Gouallec lived for approximately three years in a stable shared with two heifers and a pig. He even sympathized with the latter, which sometimes slept at his side. ${ }^{34}$ Historian Annick Le Douget (20I4: I44) compares the situation of the mentally handicapped kept at home in rural families of the Finistère with that of animals that were also living very close to humans and could share the same room. During their trials, the defendants sometimes echoed popular prejudices about the supposed endurance and insensitivity of the mentally ill. When Larose's mother was told that her daughter's feet had frozen, she exclaimed: "The insane don't freeze!" 35

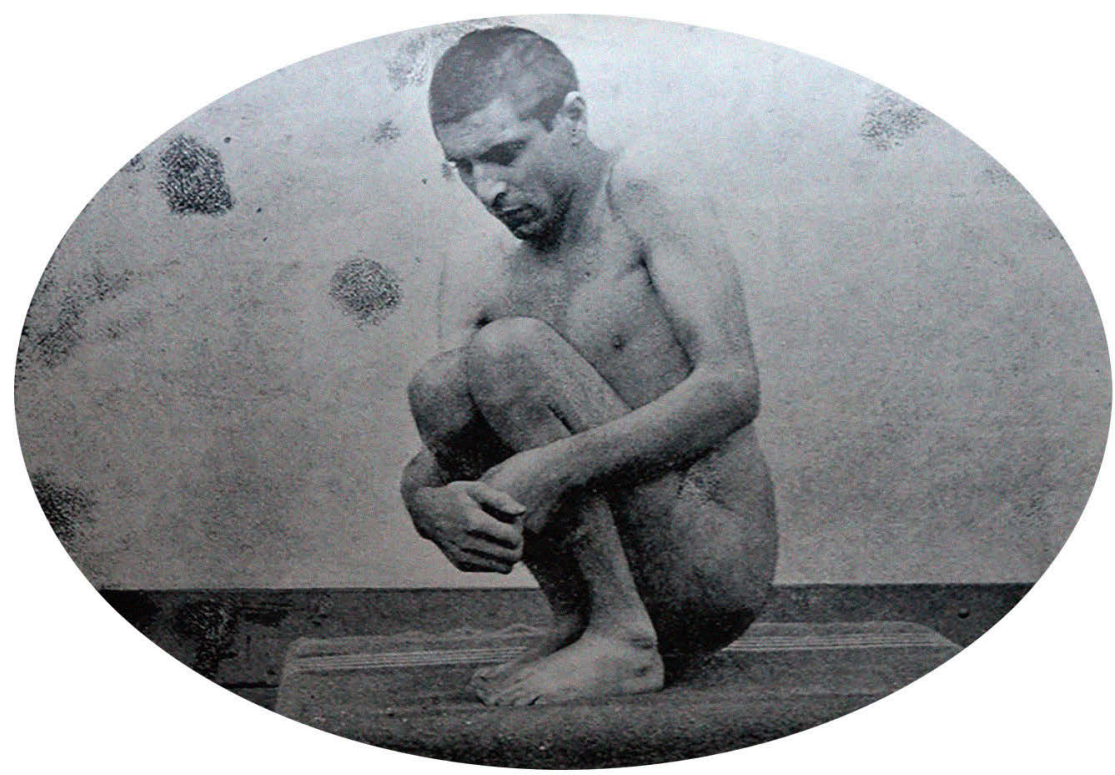


A Spatial Setting That Reveals the Place of the Insane in the Family and Community

The idea of a possible assimilation of the mentally ill and farm animals is partly corroborated by the study of the spatial settings of sequestrations. A more precise look at where the sheds were located reveals the status of confined persons in their families and village communities.

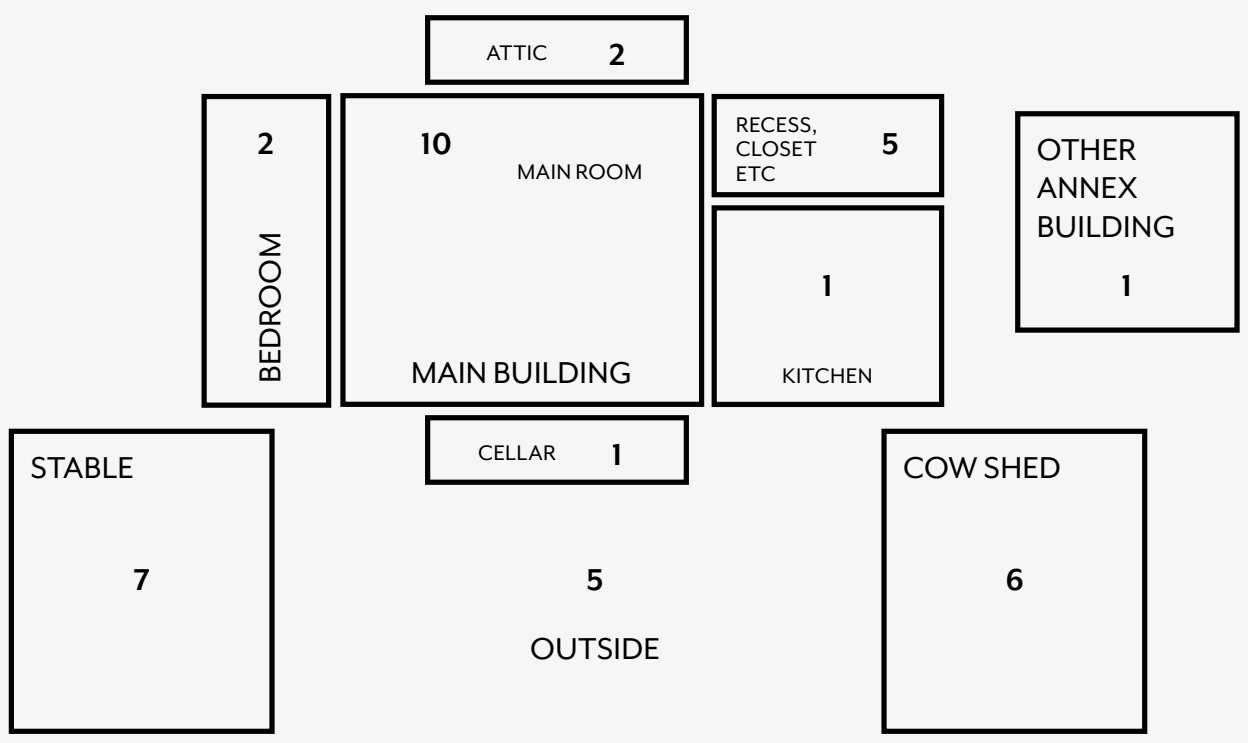


This distribution of confinement places thus offers a mixed picture (fig. 4). Approximately half the sequestrations occurred in annex buildings such as stables and cowsheds. Sometimes the shed was even located outside, in spite of the cold.

But the other half occurred in the main building, and even in the main room, showing that keeping the insane away was not perceived as necessary, and that families got used to coexisting with them. The case of Cadiou, mentioned earlier, perfectly illustrates this (fig. 2). The location of the shed where Delphine Roussel was confined (fig. 5) is also interesting: whereas plenty of other buildings could have been used, notably the cowshed (in the bottom left corner of the picture) or the stable (on the right side), Delphine's parents decided to build the shed (cabanon) in the main living area, in the room next to the kitchen.

This proximity implied regular contacts, interactions, and conversations. During the trial, the criminal charges noted with astonishment that during the previous winter the Roussel parents had gathered the family and had a celebratory meal just a few meters away from the shed where the daughter was still locked. This setting, which involved proximity and exclusion at the same time, resulted in what can be called a situation of relegated proximity.

This isolation of the mentally ill could be an attempt to hide him or her from the view of the neighbors. Magistrates and investigators usually described the incriminated families as "solitary," and their dwelling places as "isolated farmhouses." This suggests that in central villages with contiguous dwellings, not to mention urban settings, there might have been higher pressures on the families to take the initiative to commit the mentally ill to institutions. In Roussel's case, several witnesses explained to the police that whenever they paid a visit to the family, they were allowed to enter the yard, but never the main building, where Delphine was confined. Families were willing to delineate a private sphere around the mentally ill and defend it against intrusions.

Total secrecy was impossible, though. Information was constantly circulating. However distant the farms were from one another, members of rural communities were constantly watching and thereby monitoring each other's behavior. In many trials, the depositions of witnesses clearly showed that the very fact of the sequestration was rarely ignored by the neighbors, even if they generally claimed that they thought the person confined was well treated. The families sought discretion rather than secrecy. Once again, the Le Gouallec case offers a fascinating example of how the sequestration of the insane, without being concealed from the community, was nonetheless excluded from the sphere of discussion. A former friend of 


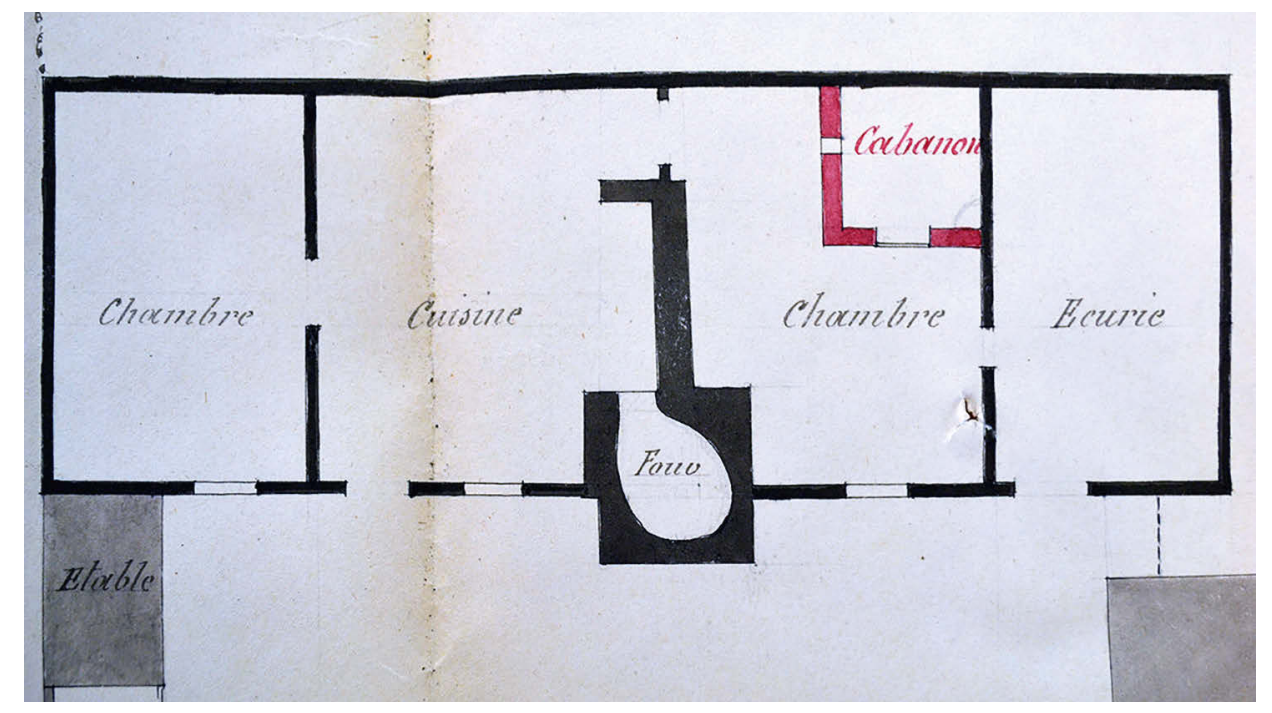

Albin related one of his conversations with the father: "I asked to see Albin but he wouldn't let me, I told him that if he didn't let me see him I would speak badly of her daughter who is about to get married; on my insistence he finally opened the door, which was locked, and let me in alone with Albin." ${ }^{36}$ Thus, relatives or neighbors could be allowed to see Albin in the stable - but only if they insisted. Although confined, Albin was integrated into the rites of collective life. A witness explained that twice a year, after the assembly of the village community at the Flowers Chapel, relatives and friends of the Le Gouallec family would go for lunch at their farm. After the meal, everybody paid a visit to Albin, who was dressed in a white shirt and had been given some fresh straw for the occasion. Le Gallo, a day laborer from the same village, also testified: "They did not really talk about it and did not appreciate Albin being visited, so I abstained from doing it; however, after the pilgrimage to the Flowers Chapel, the prohibition being lifted, I yielded to curiosity and I did like the others; I saw Albin lying in the stable." ${ }^{37}$ Although family members knew they could not completely hide the sequestration, they struggled to evade public discussion and to reaffirm their authority over the insane - not without accepting some compromises. 


\section{Conclusion}

During the second half of the I9th century, psychiatrists made the shed a symbol of the archaic attitudes of the colonized peoples as well as the French peasants in their struggle to defend the asylum as the only desirable solution. But behind the denunciatory discourses, sequestration scandals reveal a much more ambiguous attitude of legal authorities towards the family's sovereignty over their mentally ill kin, upon which the doctors and legislators were not willing to infringe. The shed was not just an archaism, a remnant of old practices doomed to disappear. It reveals the reluctance of families and local authorities to have recourse to mental institutions, even until the early 20 th century.

This study thus sheds light on a regime of "domestic psychiatry" that is quite distinct from, and maybe less idealized than the one described by Akihito Suzuki (2006). The coexistence with the sequestered lunatics was based on a regime of relegated proximity. While maintained in the family and community, the insane person was at the same time materially and symbolically put aside. The material world of the management of the mentally ill in the domestic sphere was made of adaptations ofs everyday furniture (such as closed beds, stables, etcetera), but also of structures specifically conceived for confinement, such as the shed. Most of these objects highlight the difficulties that rural families encountered when trying to cope with the mental illness of their kin. The ropes and chains that restrained the lunatics as well as the sheds and hutches that shut them away are all indications of how much families were distraught and disconcerted by the presence of mental illness in their midst, and how they improvised as they could to minimize its material, financial, as well as reputational costs. But sequestration cases probably bring out only a small part of the wide variety of tools and artifacts that were used to deal with lunatics at home, and further studies are needed to illuminate more completely the materiality of domestic care in the I 9 th century. 


\section{Notes}

1

"Le 25 avril dernier la gendarmerie de SaintValéry, de passage à Mons-Boubers, apprit que, depuis deux ans environ, la nommée Delphine Roussel, âgée de trente-trois ans, ... n'avait point quitté la maison de son père, et que ce dernier, aux questions qui lui étaient adressées, répondait toujours qu'elle était malade et gardait le lit. Les agents de l'autorité, dont les soupçons s'étaient éveillés, demandèrent à voir Delphine Roussel. Ils purent alors constater que cette malheureuse était enfermée dans un solide cabanon, construit dans le coin d'une chambre dont les volets, étaient hermétiquement clos. Dans ce réduit aux dimensions exiguës, fermé par une porte de bois plein, garnie d'un énorme verrou, Delphine Roussel, pâle et amaigrie, était accroupie sur de la paille pourrie exhalant une odeur infecte. Elle n'avait pour tout vêtement qu'un vieux jupon; des excréments étaient accumulés dans un coin ... Une ouverture pratiquée dans l'une des cloisons de ce cachot laissait à peine pénétrer l'air nécessaire à la recluse et servait à lui passer des aliments. Delphine Roussel raconta que depuis deux ans elle était confinée dans ce réduit, où elle ne voyait jamais le jour et où elle passait l'hiver sans feu et sans autre vêtement pour se garantir du froid que le jupon qui la couvrait." "La recluse de Mons-Boubers." In: Le Petitfournal, July 21, 1879, p. 3, transl. by Anatole Le Bras.

\section{2}

Breaking the Chains, documentary directed by Erminia Colucci, 2014.

\section{3}

In Charlotte Brontë's novel Jane Eyre (1847), Bertha Mason is kept secretly locked in the attic by her husband Mr. Rochester.

\section{4}

The terms "idiocy" and "imbecility" were commonly used by alienists to refer to forms of mental retardation.

\section{5}

In the past decades, a wealth of historical studies has shed a new light on the relations of families to psychiatric institutions in the 19th century, see Coleborne (2010). For France, see Prestwich (2003) and Le Bras (2016). But the domestic care of lunatics is still under-documented and studied, with the notable exception of studies using judiciary archives, see Suzuki (2006) and Nootens (2007).

\section{6}

The Gazette des tribunaux was founded in 1825 , Le Petit Journal in 1863. The Annales médicopsychologiques, founded in 1843, was the main review of French alienists, gathering all tendencies and sensibilities. A certain degree of sensationalism was of course involved in the coverage of these cases. This corpus of cases should therefore not be deemed representative of the average situation of lunatics kept at home. But I will try to show the heuristic utility of these "borderline cases."

7

These reports are often very detailed, and usually reproduce verbatim the criminal charges.

\section{8}

At the Department archives of Finistère (region of Brittany), Morbihan (ibid.), and Somme (region of Hauts-de-France).

\section{9}

See below.

10

"Séquestration d'une fille par ses parents. Horribles détails." In: Le Petit Journal, February 27, 1866, p. 3.

11

The law of June 30, 1838 imposed the presence of an asylum in each department and regulated the modes of admission to the asylum. Confinement was now a medical and administrative act, and no longer a judicial one. The full text of the law (in French) is available online at http://psychiatrie.histoire.free.fr/index.htm (Législation -> Internements -> La Loi du 30 juin 1838). 
12

Victor Parant (1848-1924) was the director of the Braqueville public asylum, near Toulouse. A regular contributor of the Société médico-psychologique, he was also an influential member of the Société de Saint-Luc, an organization of catholic doctors.

\section{3}

This case made headlines in 1901, after the police discovered a woman, named Blanche Monnier, who had been confined for more than 25 years in a bourgeois house in Poitiers (prefecture of the Vienne department). The trial led to the acquittal of her brother.

\section{4}

About the "anti-alienist" movement in France in the 19th century, see Fauvel (2005).

\section{5}

Achille Foville (1831-1887), son of Achille Louis de Foville, himself a well-known alienist, was the director of the Quatre-Mares public asylum, near Rouen.

\section{6}

As early as 1828 in England, the County Asylums Act allowed the Lord Chancellor to visit any private house where an insane person was detained. Following the 1890 Lunacy Act, some non-pauper lunatics placed in private houses (but not those treated by their close family) could also be placed under the supervision and protection of the Chancellery. But the true model of French alienists was the 1857 Scottish Lunacy Act, which established a mandatory declaration to the authorities when the lunatic had to be contained or when the mental illness lasted more than a year. The Commissioners in Lunacy could also visit any private house whenever bad treatment was suspected.

\section{7}

Vaillant's proposal was to make home treatment subject to a judicial authorization.

\section{8}

On the topic of family life in 19th-century France, see Perrot (2015).
19

The total number (49) is greater than the number of cases (47) because there were two cases of double sequestrations.

\section{0}

25 sequestrated people were below 30 when the confinement began; ten were between 30 and 50; and five above 50 (the information could not be found for the remaining nine).

\section{1}

Deposition of Royau, Case file of Le Gouallec, 2U2/561, Morbihan Department archives, Vannes France.

\section{2}

Deposition of Victor Le Gouallec, case file of Le Gouallec, 2U2/561, Morbihan Department archives, Vannes, France.

\section{3}

If the family had recourse to a "voluntary placement," it had to pay for the entire cost of the stay; if a "placement d'office" was requested by the prefect, the department paid for most of the costs, but the municipality and the family were also expected to contribute at a variable rate, depending on their level of income.

\section{4}

"Une folle. Séquestration. Mort." In: La Gazette des tribunaux, August 16-17, 1841, pp. 1080-1081.

\section{5}

The doctors of Quimper public asylum sometimes noted that patients had been locked in a closed bed before being sent to the asylum, see Le Bras (2016).

\section{6}

"Jeune fille séquestrée." In: Le Petit Journal, July 10, 1903, p. 5.

\section{7}

Criminal charges, case file of Le Gouallec, 2U2/561, Morbihan Department archives, Vannes, France.

28

"Séquestration d'une jeune fille par son père 
et sa mère." In: La Gazette des tribunaux,

December 19, 1873, p. 1240.

\section{9}

"Séquestration." In: La Gazette des tribunaux, September 14, 1877, p. 892.

30

"Séquestration d'une mère par son fils." In: La Gazette des tribunaux, June 26, 1874, p. 608.

31

"Séquestration." In: La Gazette des tribunaux, November 2, 1890, p. 1049.

\section{2}

The publication of the case file was the second volume in a new collection by Gallimard called "Nejugez pas!" ["Don't judge!"], published in 1930.

\section{3}

"Une folle. Séquestration. Mort." In: La Gazette des tribunaux, August 16-17, 1841, pp. 1080-1081.

\section{4}

Interrogation of Albin Le Gouallec, case file of Le Gouallec, 2U2/561, Morbihan Department archives, Vannes, France.

\section{5}

"Séquestration d'une fille, par son père et sa mère. Deux ans de martyre. Horribles détails." In: Le Petit Journal, June 10, 1865, p. 3.

\section{6}

"Je lui dis que ... s'il ne me laissait pas voir Albin [je] dirai du mal [de sa fille], à force d'insister, il m'a conduit à l'écurie, il a ouvert la porte qui était fermée à clef et il m’a laissé seul avec Albin." Deposition of François Kergouët, case file of Le Gouallec, 2 U2/561, Morbihan Department archives, Vannes, France. Transl. by Anatole Le Bras.

\section{7}

"On en parlait peu dans la maison et on n'aimait pas que l'on allât le visiter, je m'en suis abstenu; cependant à l'époque du pardon des fleurs, l'interdiction paraissant levée, j'ai cédé à la curiosité et jai fait comme les autres, j’ai vu Albin couché dans une écurie ..." Deposition of Le Gallo, case file of Le Gouallec, 2 U2/561, Morbihan

Department archives, Vannes, France.

Transl. by Anatole Le Bras.

\section{Bibliography}

Baume, Irénée-Célestin (1874): "Affaire Albin Le Gouallec. Séquestration dans une écurie avec emploi d'une chaîne. Rapport médico-légal." In: Annales médico-psycholoqiques 11-12, pp. 411-420.

Bourneville, Désiré-Magloire (1889): "De l'assistance des aliénés dans les hôpitaux-hospices de province." In: Le Progrès medical 2/9, pp. 31-33.

Coleborne, Catharine (2010): Madness in the Family. Insanity and Institutions in the Australasian Colonial World, I860-I9I4, New York: Palgrave Macmillan.

Colucci, Erminia (2014): "Breaking the Chains." Movie-Ment, http://movie-ment.org/breakingthe chains, accessed March 26, 2020.

Fauvel, Aude (2005): Témoins aliénés et "Bastilles modernes": une histoire politique, sociale et culturelle des asiles en France (I8OO-I9I4), dissertation, Paris: École des hautes études en sciences sociales. Foville, Achille (1870): "De la législation spéciale aux aliénés et des améliorations qu'il serait possible d'apporter à la loi du 30 juin 1838." In: Annales d'hygiène publique et de médecine légale 2/33, pp. 381-420. Gide, André (1930): La Séquestrée de Poitiers, Paris: Gallimard.

Girma/Vernet (1894): "Un cas de séquestration d'un aliéné par ses parents." In: Annual Congress of Mental Medicine, La Rochelle, 1-6 August 1893, pp. 720-723.

Hubert, René (1902): Protection légale des aliénés en France, Paris: Arthur Rousseau éditeur. 
Izard, Gabriel (1903): Séquestration des aliénés dans la famille, Bordeaux: J. Durand.

Le Bras, Anatole (2016): "L'asile d'aliénés et le désordre des familles." In: Revue d'histoire du XIXe siècle 53, pp. 171-187.

Le Douget, Annick (2014): Violence au village. La société rurale finistérienne face à la justice, I8I5I9I4, Rennes: Presses Universitaires de Rennes.

Lwoff, Solomon/Sérieux, Paul (1911): "Sur quelques moyens de contrainte appliqués aux aliénés au Maroc." In: Bulletin de la Société clinique de médecine mentale, pp. 168-174.

Majerus, Benoît (2011), "La baignoire, le lit et la porte. La vie sociale des objets de la psychiatrie." In: Genèses 82, pp. 95-119.

Monod, Henri (1889): "'Les cellules d'observation des aliénés dans les hospices.' Congress of Mental Medicine, 9 August 1889." In: Archives de neurologie 18, pp. 304-313.

Nootens, Thierry (2007): Fous, prodigues et ivrognes. Familles et déviance à Montréal au XIXe siècle, Montreal/Kingston/London/lthaca: McGill-Queen's University Press.

Parant, Victor (1884): De la séquestration des aliénés dans leur famille, Paris: Rougier.

Perrot, Michelle (2015): La vie de famille au XIXe siècle, Paris: Seuil.

Petit, Jacques-Guy (1980): "Folie, langage, pouvoirs en Maine-et-Loire (1800-1841)." In: Revue

d'histoire moderne et contemporaine 27, pp. 529 $-564$.

Prestwich, Patricia (2003): "Family Strategies and Medical Power: Voluntary committal in a Parisian Asylum, 1876-1914." In: Porter, Roy/Wright, David (eds.): The Confinement of the Insane: International Perspectives, I80o-1965, Cambridge: Cambridge University Press, pp. 79-99. Reboul, Henri/Régis, Emmanuel (1912): L'assistance des aliénés aux colonies, Paris: Masson. Suzuki, Akihito (2006): Madness at Home. The Psychiatrist, the Patient, and the Family in England, I820-I860, Berkeley: University of California Press.

Wright, David (1997): "Getting Out of the Asylum. Understanding the Confinement of the Insane in the Nineteenth-Century." In: Social History of Medicine 10, pp. 137-155.

Wright, David (1998): "Familial Care of 'Idiot' Children in Victorian England." In: Horden, Peregrine/Smith, Richard (eds.): The Locus of Care. Families, Communities, Institutions and the Provision of Welfare since Antiquity, London: Routledge, pp. 176-197.

\section{Newspapers}

"Une folle. Séquestration. Mort." In: La Gazette des tribunaux, August 16-17, 1841, pp. 1080-1081.

"Séquestration d'une fille, par son père et sa mère. Deux ans de martyre. Horribles détails." In: Le Petit Journal, June 10, 1865, p. 3.

"Séquestration d'une fille par ses parents. Horribles détails." In: Le Petit Journal, February 27, 1866, p. 3.

"Séquestration d'une jeune fille par son père et sa mère." In: La Gazette des tribunaux, December 19, 1873, p. 1240.

"Séquestration d'une mère par son fils." In: La Gazette des tribunaux, June 26, 1874, p. 608.

"Séquestration." In: La Gazette des tribunaux, September 14, 1877, p. 892

"La recluse de Mons-Boubers." In: Le Petit Journal, July 21, 1879, p. 3.

"Jeune fille séquestrée." In: Le Petit Journal, July 10, 1903, p. 5.

The author thanks Marion Henry, Monika Ankele, Benoît Majerus, and Anthony DePasquale for their remarks and proofreading. 